\title{
Self-punitive responding in rats with goal shock and color change
}

\author{
HARRY L. HOM, JR. and HAROLD BABB \\ University of Montana, Missoula, Montana 59801
}

\begin{abstract}
After acquisition avoidance training, rats were assigned on the basis of matched run speed to the following groups: (1) maintenance of avoidance training, (2) extinction procedures with the addition of a brief shock in the goalbox, and (3) regular extinction procedures. Each group was further divided into two minor groups which experienced either change or no change in goalbox color. The results indicated: (1) that self-punitive responding was increased by goal shock, (2) that self-punitive responding was reduced by goalbox color change, and (3) that generalization of goal shock to the startbox and runway areas is a factor in self-punitive responding.
\end{abstract}

Evidence of perseverating self-punitive behavior in the straight runway situation and of the generality of the phenomenon has been noted in two review articles devoted to the subject (Brown, 1969; Melvin, 1971). Mowrer (1950) was the first to report an observation by J. S. Brown that if animals were presented with shock escape training in a straight runway, the subsequent administration of shock in some intermediate portion of the alley served to maintain the running response.

Failure to replicate the self-punitive effect has occurred on occasion. This failure has appeared when utilizing a shuttlebox apparatus (Imada, 1959; Kamin, 1959; Misanin, Smith, \& Campbell, 1966; Smith, Misanin, \& Campbell, 1966) and in a runway situation with the application of shock in an intermediate portion of the alley (Seward \& Raskin, 1960), or near the goalbox (Campbell, Smith, \& Misanin, 1966; Seward, King, Chow, \& Shiflett, 1965). Although involving a different theoretical framework, Eison and Sawrey (1967) and Kintz and Bruning (1967) reported results consistent with those of Seligman and Campbell (1965) indicating the absence of self-punitive behavior with the application of shock in the goalbox.

Regarding the latter findings, Babb (1963) found that the presentation of $5 \mathrm{sec}$ shock in the goalbox after shock escape training failed to produce a significant degree of reduced responding. Subsequently, there were further modifications of his procedure which were thought to enhance generalization of goalbox shock back to the startbox and runway areas and, hence, maintain responding. These refinements were: (1) shortening the duration of shock, (2) using a more distinctive CS, and (3) applying shock immediately after the subject entered the goalbox. These modifications

This report is based on a dissertation submitted in partial fulfillment of the requirements for the $\mathrm{PhD}$ degree from the University of Montana by the senior author. Requests for reprints should be sent to Harry L. Hom, Jr., who is now at the Department of Psychology, Southwest Missouri State University, Springfield, Missouri 65802 . Harold $\mathrm{Babb}$ is now at State University of New York at Binghamton. resulted in a successful demonstration of self-punitive behavior with shock applied in the goalbox after either avoidance or escape training (Babb \& Hom, 1971). These results for the first time extended the self-punitive phenomenon to include an experimental paradigm whereby shock was applied at the termination of an operationally defined response. Moreover, an inspection of the data suggested the likelihood that the experimental groups did exhibit an acceleration in performance. It was thought that the experimental manipulation of goal shock was not only maintaining prior conditions but also serving to increase response speed. An assessment of this effect was not possible since it was unexpected and the appropriate control groups had not been included in the experiment.

The present study was designed with two main objectives. First, if generalization of goal shock back to the startbox and runway areas is a significant factor in producing self-punitive behavior, then a corresponding reduction in generalization of fear should result in decreased evidence of self-punitive responding. Goal shock in direct association with a specific and discriminable locale could be expected to reduce responding through making the goalbox distinctive. The first objective was attempted by changing the color of the goalbox after acquisition training.

The second objective of the present study was to determine whether or not an experimental group receiving shock in the goalbox would show evidence of increased response speed rather than response maintenance. This assessment was thought important since an adequate explanation of Babb \& Hom's (1971) results requires consideration of such acceleration in performance. The second objective was accomplished by the use of an added control group, one that was maintained in the self-punitive phase under the original conditions of ayoidance training. This procedure is in contrast to that employed by most investigators in the use of a regular extinction group as a control group for an estimate of self-punitive responding. 


\section{METHOD}

Subjects

The subjects were 48 Long-Evans hooded rats from Blue-Spruce Farms. All subjects were males and approximately 110-130 days old on the 1st day of pretraining.

\section{Apparatus}

The apparatus was one previously used by Babb \& Hom (1971) with a $121.92-\mathrm{cm}$ runway with $30.48-\mathrm{cm}$ startbox and goalbox extensions. It contained a steel grid floor throughout the startbox, runway, and goalbox, with Plexiglas doors and a Plexiglas top. The doors were guillotine type with a characteristic superstructure rising above the top of the alley. Except for the floor, doors, and top, the entire structure was painted a flat, medium gray. Hunter infrared light sources, silent photoelectric relays, and silent timers were used to measure start speed, run speed, and goalbox entry speed. The latter consisted of the measured time between the interruption of the terminal beam for run speed and the lowering of the goalbox door.

A buzzer CS sounded at approximately $75 \mathrm{~dB}$ (re .0002 dynes $\left(\mathrm{cm}^{2}\right.$ ) às measured by a Brüel and Kajar sound level meter Model 2203, with octave filter set Model 1613, at the startbox entrance. The ambient noise level was approximately $65 \mathrm{~dB}$. This buzzer was initiated at the opening of the startbox door and remained in operation until the goalbox door was lowered within $2.54 \mathrm{~cm}$ of the grid floor. In addition, the buzzer was located $5.08 \mathrm{~cm}$ in front of the exterior end wall of the startbox and was cushioned on foam rubber.

Shock was administered in the startbox, runway, or the goalbox in the following manner. It was delivered in the startbox and runway after the 3-sec CS-UCS interval and was terminated when the animal entered the goalbox. The CS-UCS interval was measured with a Hunter decade interval timer which was started by the opening of the startbox door. Shock was administered in the goalbox for $.5 \mathrm{sec}$ with another Hunter decade interval timer and was initiated by the closure of the goalbox door to a distance of $2.54 \mathrm{~cm}$ from the grid floor. An Applegate constant-current electric stimulator and a Davis shock scrambler were used to deliver shock.

\section{Procedure}

The experiment contained three phases: pretraining, acquisition, and transfer (self-punitive phase). Each subject was handled for $3 \mathrm{~min}$ during pretraining for a period of 7 days. Acquisition and transfer training consisted of 30 trials and 80 trials, respectively, administered at the rate of 5 per day with an intertrial interval of $5 \mathrm{~min}$. On each trial, the subject was placed in the startbox with the door opening on a random basis, between 15 and $30 \mathrm{sec}$. The buzzer was initiated by the opening of the startbox door and was terminated by the goalbox closure after the subject's entry into the goalbox. Goalbox confinement consisted of a 30 -sec period.

During acquisition avoidance conditioning, after a CS-US interval of $3 \mathrm{sec}$, a shock of 1-mA intensity was administered throughout the startbox and runway, regardless of the animal's position in that area. Termination of shock occurred when the animal entered the goalbox. In acquisition, shock was never delivered in the goalbox area for any of the subjects.

At transfer, a 2 by 3 randomized block factorial design was utilized. On the basis of matched run speed over the last 15 trials of acquisition, the subjects were divided into three major groups: (1) extinction procedures with the addition of a 1-mA shock immediately on entrance into the goalbox for $.5 \mathrm{sec}$, (2) maintenance of acquisition avoidance procedures, and (3) regular extinction procedures. Each of the major groups was further divided into two subgroups which experienced either: (a) goalbox color change or (b) no goalbox color change. Change in color was accomplished by inserting white panels. Subgroups compared in the results are designated as $\mathrm{E}$ for shock in the goalbox, Av for maintenance of avoidance training, and Re for regular extinction procedures. In addition, the $\mathrm{D}$ or $\mathrm{S}$ enclosed in parentheses refers to goalbox change, or no change, respectively.

While the shock procedure was continued for the transfer phase in the startbox and runway for $A v(S)$ and $A v(D)$, it was discontinued for the other two major groups $(\mathrm{E}, \mathrm{Re})$. However, an important difference between the latter two groups was that $\mathrm{Re}$ groups never received shock under regular extinction procedures while $\mathbf{E}$ groups received shock immediately upon entering the goalbox, when the goalbox door closed within $2.54 \mathrm{~cm}$ of the grid floor.

All subjects were run either to completion of 80 transfer triais or until extinction criteria were met. If a subject remained in the startbox and runway areas for a duration of $60 \mathrm{sec}$, the subject was eliminated from further testing and assigned a score of $60 \mathrm{sec}$, for the remainder of transfer testing.

\section{RESULTS}

Start speed, run speed, and goalbox entry speed were recorded and transformed to reciprocals. The data were subjected to a 2 by 3 randomized block factorial analysis and individual comparisons were made with the Tukey's HSD test (Winer, 1962). All analyses were two tailed and .05 was accepted as the level of significance. Transfer data were analyzed in blocks of Transfer Days 1-5, 6-12, and 6-16, while the acquisition data were analyzed for Days 1-6. These transfer days were chosen because they generally reflected performance changes throughout the course of transfer training. In addition, the data were subjected to an analysis involving Mann-Whitney $U$ tests (Siegel, 1956) for unequal subjects.

\section{Start Speed}

In acquisition, there were no significant differences among the six groups in start speed $(F=.68 ; \mathrm{df}=5 / 15$; $\mathrm{p}>.05)$, run speed $(\mathrm{F}=.46 ; \mathrm{df}=5 / 15 ; \mathrm{p}>.05)$, number of successful avoidance trials $(F=1.12 ; \mathrm{df}=5 / 15$; $p>.05)$, and amount of shock $(F=1.12 ; \mathrm{df}=5 / 15$; $\mathrm{p}>.05)$. As expected, there was a significant blocks effect that reflected matched run speeds $(F=29.37$; $\mathrm{df}=3 / 15 ; \mathrm{p}<.01$ ).

In transfer, no overall treatment effects were found for start speed on either Transfer Days 1-5 ( $F=2.60$; $\mathrm{df}=5 / 15 ; \mathrm{p}>.05)$ or Days 6-16 $(\mathrm{F}=2.91 ; \mathrm{df}=5 / 15$; $p>.05$ ) when using all subjects in the statistical analyses. Further examination of the data for subjects which did not meet the extinction criteria suggested that there might be significant differences among the groups involving Transfer Days 1-5 and 6-12 (see Table 1 for means of median start speed).

The numbers of subjects included in the analyses were eight, four, seven, and five, respectively, for Groups $\mathrm{E}(\mathrm{S}), \mathrm{E}(\mathrm{D}), \operatorname{Re}(\mathrm{S})$, and $\operatorname{Re}(\mathrm{D})$ on Transfer Days 1-5. However, the analyses on Days 6-16 were not possible due to only one subject's running in $\operatorname{Re}(\mathrm{S})$. Therefore, the statistical analyses were run on Days 6-12 and involved the following number of subjects: six for $E(S)$, four for $E(D)$, four for $\operatorname{Re}(S)$, and four for $\operatorname{Re}(D)$.

Due to the unequal number of subjects in each of the 
treatment groups, the differences were assessed with Mann-Whitney U tests (Siegel, 1956). With these analyses, there were no significant differences among the groups for Days 1-5. However, for Transfer Days 6-12, $E(S)$ started significantly faster than $\operatorname{Re}(S)(p=.038)$ but did not differ significantly from $\operatorname{Av}(S)(p=.228)$. There was evidence of self-punitive responding for the E(S) group, but there was no evidence of an increased start speed when comparing $\mathrm{E}(\mathrm{S})$ to its appropriate Control Group $\mathrm{Av}(\mathrm{S})$.

\section{Run Speed}

Run speeds were significantly different on Transfer Days 1.5 for experimental treatment $(\mathrm{F}=5.62$; df $=5 / 15 ; p<.05)$, goalbox change $(F=8.77$; $\mathrm{df}=1 / 15 ; \mathrm{p}<.05)$ and for the interaction term $(F=5.06, d f=2 / 15 ; p<.05)$ (see Figure 1 for the means of median run speed). The blocks effect proved to be nonsignficant $(F=2.36 ; d f=3 / 15 ; p>.05)$, indicating that the matched run speeds did not carry over to transfer training. As seen in Figure 1, the main groups experiencing goal shock or the avoidance contingency ran faster than the groups run under regular extinction procedures. With the exception of $\operatorname{Av}(D)$ 's performing at a slightly higher speed than $\operatorname{Av}(S)$, the groups experiencing a change in goalbox color, E(D) and $\operatorname{Re}(\mathrm{D})$, ran slower than the groups receiving no change in the goalbox color, $E(S)$ and $\operatorname{Re}(S)$. The only individual comparison of interest which was significant was that the $E(S)$ group ran significantly faster than the $E(D)$ group, according to the Tukey's test $(p<.05)$ and the $\mathrm{U}$ test $(\mathrm{p}=.006)$.

On Transfer Days 6-16, run speeds were significantly different for experimental treatment $(F=14.29$; $\mathrm{df}=2 / 15 ; \mathrm{p}<.01)$ but not for blocks $(\mathrm{F}=.76$; $\mathrm{df}=3 / 15 ; \mathrm{p}>.05)$, goalbox change $(\mathrm{F}=1.52$; $\mathrm{df}=1 / 15 ; \mathrm{p}>.05)$, or the interaction term $(\mathrm{F}=2.29$; $\mathrm{df}=2 / 15 ; \mathrm{p}>.05)$. As seen in Figure 1 , the major experimental groups receiving goal shock or the avoidance contingency ran faster than the major group run under regular extinction procedures. Consistent with the significant main effect, $\mathrm{E}(\mathrm{S})$ ran significantly faster than $\operatorname{Re}(S)$, according to the Tukey's HSD test $(\mathrm{p}<.05)$ and the $U$ test $(p=.05)$, and showed self-punitive responding for the $E(S)$ group.

No evidence of increased run speed was provided by comparing the run speed of $E(S)$ to its appropriate Control Group $\mathrm{Av}(\mathrm{S})$ when using all subjects in the data analyses. However, an examination of the data for

Table 1

Start Speed for Transfer Days 1-5 and 6-12 Excluding Extinguished Subjects

\begin{tabular}{lcccccc}
\hline $\begin{array}{c}\text { Transfer } \\
\text { Days }\end{array}$ & $\begin{array}{c}\mathrm{E} \\
\text { (S) }\end{array}$ & $\begin{array}{c}\mathrm{E} \\
\text { (D) }\end{array}$ & $\begin{array}{l}\text { Av } \\
\text { (S) }\end{array}$ & $\begin{array}{c}\text { Av } \\
\text { (D) }\end{array}$ & $\begin{array}{c}\text { Re } \\
\text { (S) }\end{array}$ & $\begin{array}{l}\text { Re } \\
\text { (D) }\end{array}$ \\
\hline $1-5$ & 1.75 & 1.81 & 2.07 & 1.52 & 1.49 & 1.54 \\
$6-12$ & 2.32 & 2.32 & 1.97 & 1.96 & .95 & 1.88 \\
\hline
\end{tabular}

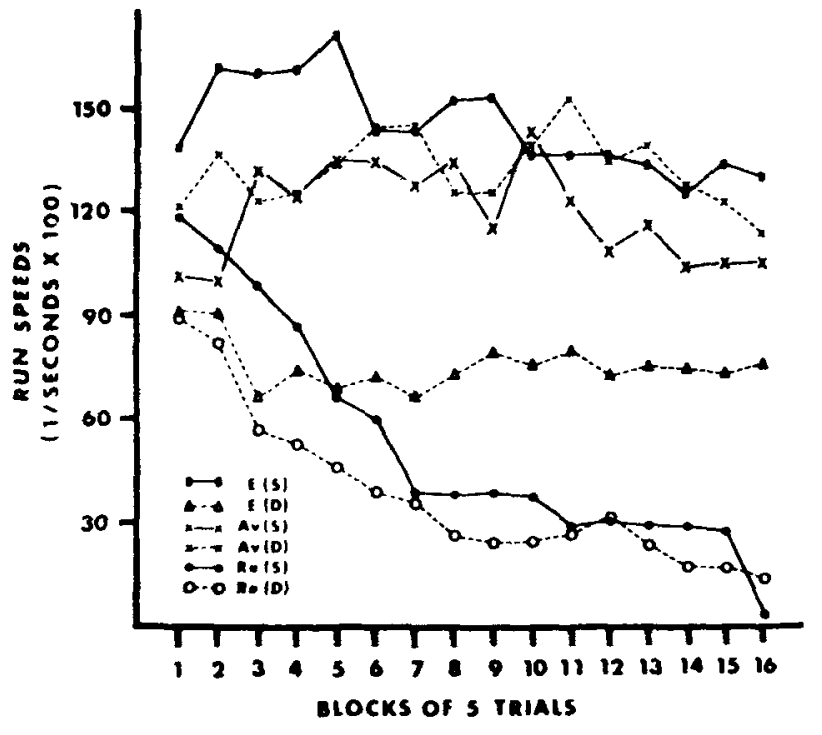

Figure 1. Run speed in transfer using all subjects.

individual subjects that had not reached the extinction criteria showed that $E(S)$ might be running faster than $\operatorname{Av}(S)$ (see Figure 2). A Mann-Whitney $U$ test indicated that this apparent difference was significant for Transfer Days $1-5(p=.01)$ as well as for Days $6-12(p=.012)$. In addition, $E(S)$ ran significantly faster than $\operatorname{Re}(S)$ both on Days $1.5(p=.02)$ and $6-12(p=.01)$. There was some evidence of increased run speed in that the $E(S)$ group ran significantly faster than the $\operatorname{Av}(S)$ group, when using in the statistical analyses only subjects which were still running.

\section{Goalbox Entry Speed}

Goalbox entry speed was employed as an added measure to further substantiate that the subjects had discriminated the change in goalbox color. The statistical analyses were run on Transfer Day 1 for Trial 1 only. On Trial 1, there were significant experimental treatment $(F=5.37 ;$ df $=2 / 15 ; p<.05)$, blocks effect $(F=9.87$; $\mathrm{df}=3 / 15 ; \mathrm{p}<.01)$, and goalbox change $(\mathrm{F}=72.20$; $\mathrm{df}=1 / 15 ; \mathrm{p}<.01)$; with a nonsignificant interaction term $(F=.80 ; d f=2 / 15 ; p>.05)$. In keeping with the significant main effect of goalbox change, individual comparisons showed that all groups experiencing a goalbox change entered significantly slower than the groups receiving no change in goalbox color $(p<.05)$. This was consistent with the $U$ test comparing $E(S)$ vs. $\mathrm{E}(\mathrm{D})(\mathrm{p}=.01)$, and $\operatorname{Re}(\mathrm{S})$ vs. $\operatorname{Re}(\mathrm{D})(\mathrm{p}=.006)$ but not for $\operatorname{Av}(S)$ vs. $\operatorname{Av}(D)(p=.104)$. Finally, evidence of agitated behavior, defined as the animal's pushing against the top of the goalbox lid during the confinement period after each trial, was observed in the subjects of the two groups which received shock in the goalbox and, in particular, in the $\mathrm{E}(\mathrm{S})$ group. 


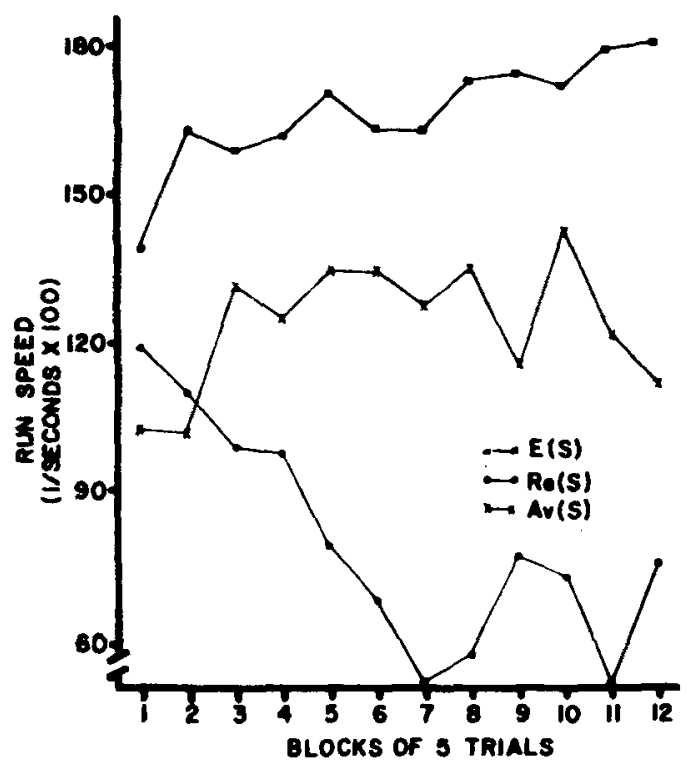

Figure 2. Run speed in transfer excluding extinguished subjects.

\section{DISCUSSION}

The results of the present study were consistent with the earlier findings of Babb \& Hom (1971) and constitute a replication of their goalbox shock procedure. Moreover, the manipulation of goalbox change proved to be of importance in reducing the self-punitive effect. The results suggest that generalization of goal shock is important in producing the self-punitive effect, as demonstrated by decreased responding with goalbox change. In addition, there was evidence that goal shock acts to increase running speed along with its generalization aspects. This was indicated by evidence for increased run speed in one of the analyses. The failure to find an increased start speed may be attributable to the short response length involved in start speed and, hence, a ceiling effect.

The present results were contradictory to a number of recent findings by Brown and his associates (Brown, 1970; Brown, Beier, \& Lewis, 1971). The latter investigators found that a distinctively marked shock zone did not reduce the self-punitive effect. The difference between their results and the present ones may be due to a procedural and apparatus variation, specifically, the location of shock in the self-punitive phase of training. In both of the cited studies by Brown, shock was presented in an intermediate portion of the runway as compared to goal shock in the present study.

Dreyer and Renner (1971) contend that self-punitive behavior is due to the failure to discriminate a change in experimental conditions between prior training and the self-punitive phase of training. The general assumption made by these investigators is that once such a discrimination occurs, self-punitive responding ceases.
Most appropriately, Crowell, Brown, and Lewis (1972) pointed out that the criterion employed by the former investigators for specifying a lack of discrimination on the part of subjects was self-punitive running. In addition, Crowell et al. (1972) have indicated a need for specifying objective and independent measures other than self-punitive responding for evidence that the subjects failed to discriminate a change in experimental conditions. Finally, they noted that the subject may discriminate a change in experimental conditions but may or may not inhibit a response leading to shock. The present data indicate that it is doubtful that failure to discriminate, a relatively simple explanation of self-punitive responding, can provide an adequate account of the phenomenon. Both $E(S)$ and $E(D)$ showed evidence of discriminating a change in experimental conditions. For E(D), this discrimination of change led to reduced self-punitive responding, and for $E(S)$ there was continued self-punitive responding and, in some cases, even increased self-punitive behavior. Although E(S) subjects showed, to some extent, a discrimination of change in the experimental conditions, this did not preclude the possibility that generalization is still present in the experimental situation. In contrast, for $E(D)$, greater amounts of discrimination may have occurred with goalbox change, thereby decreasing generalization of goal shock change to earlier conditions of training.

The discrepancy between the present data and the results of Brown and his associates can be resolved only through further experimentation. Such experiments should be designed to compare the effects of goal shock and runway shock on response measures during the self-punitive phase of training. In addition, further research is necessary in response to those studies employing goal shock (Eison \& Sawrey, 1967; Kintz \& Bruning, 1967; Riccio \& Marrazo, 1972; Seligman \& Campbell, 1965) where there was failure to find evidence of self-punitive responding. One factor which may be important is that none of these studies employed a safety period after the initial receipt of shock in the goalbox. This procedure could be expected to increase goalbox aversion and lead to reduced responding.

\section{REFERENCES}

Babb, $H$. Reinforcement and punishment of an escape response. Psy chological Reports, 1963, 13, 542.

Babb, H., \& Hom, H. L., Jr, Self-punitive behavior with goal shock. Joumal of Comparative and Physiological Psychology. $1971,77,482-488$.

Brown, J. S. Factors affecting self-punitive locomotor behavior. In B. A. Campbell and R. M. Church (Eds.). Punishment and aversive behavior. New York: Appleton-Century-Crofts, 1969. Pp. 467-514.

Brown, J, S. Self-punitive behavior with a distinctively marked punishment zone. Psychonomic Science, 1970, 21, 161-162.

Brown, J. S., Beier, E. M., \& Lewis, R. W. Punishment-zone distinctiveness and self-punitive locomotor behavior in the rat. Journal of Comparative and Physiological Psychology, 1971, 77, 513-520.

Campbell, B. A., Smith, N. F., \& Misanin, J. R. Effects of punishment on extinction of avoidance behavior: Avoidance-avoidance conflict or vicious circle behavior? 
Journal of Comparative and Physiological Psychology, 1966, $62,495-498$.

Crowell, C. R., Brown, J. S., \& Lewis, R. W. Self-punitive behavior in the rat during successive-discrimination "extinction" trials. Psychonomic Science, 1972, 27, 131-135.

Dreyer, P., \& Renner, K. E. Self-punitive behavior-Masochism or confusion? Psy chological Review, 1971, 78, 333-337.

Eison, C. L., \& Sawrey, J. M. Extinction of avoidance behavior: CS presentation with and without punishment. Psychonomic Science, 1967, 7, 95-96.

Imada, H. The effects of punishment on avoidance behavior. Japanese Psychological Research, 1959, 1, 27-38.

Kamin, L. J. The delay-of-punishment gradient. Journal of Comparative and Physiological Psychology, 1959, 52, 434-437.

Kintz, B. L., \& Bruning, J. L. Punishment and compulsive avoidance behavior. Journal of Comparative and Physiological Psy chology, 1967, 63, 323-326.

Melvin, K. B. Vicious circle behavior. In H. D. Kimmel (Ed.), Experimental Psychopathology: Recent research and theory. New York: Academic Press, 1971. Pp. 95-115.

Misanin, J. R., Smith, N. F., \& Campbell, B. A. Durations of punishment and the delay of punishment gradient. Canadian Journal of Psychology, 1966, 20, 407-412.

Mowrer, O. H. Learning theory and personality dynamics. New York: Ronald Press, 1950.
Riccio, D. C., \& Marrazo, M. J. Effects of punishing active avoidance in young and adult rats. Journal of Comparative and Physiological Psychology, 1972, 79, 453-458.

Seligman, M. E. P. \& Campbell, B. A. Effects of intensity and duration of punishment on extinction of an avoidance response. Journal of Comparative and Physiological Psychology, 1965, 59, 295-297.

Seward, J. P., King, R. M., Chow, T., \& Shiflett, S. C. Persistence of punished escape responses. Journal of Comparative and Physiological Psychology, 1965, 60, 265-268.

Seward, J. P., \& Raskin, D. C. The role of fear in aversive behavior. Journal of Comparative and Physiological Psychology, 1960, 53, 328-335.

Siegel, S. Nonparametric statistics for the behavioral sciences. New York: Mc Graw-Hill, 1956.

Smith, N. F., Misanin, J, R., \& Campbell, B. A. Effect of punishment on extinction of an avoidance response: Facilitation or inhibition? Psychonomic Science, 1966, 4 271-272.

Winer, B. J. Statistical principles in experimental design. New York: MeGraw-Hill, 1962.

(Received for publication October 2, 1974; accepted January 3, 1975.) 